\title{
STUDIES IN EDEMA. II. THE EFFECT OF CONGESTIVE HEART FAILURE ON SALIVA ELECTROLYTE CONCENTRATIONS
}

\author{
BY ABRAHAM G. WHITE,1 HAROLD GORDON,2 AND LOUIS LEITER
}

(From the Medical Division, Montefiore Hospital, New York City)

(Submitted for publication June 20, 1950; accepted, July 24, 1950)

In congestive heart failure the urinary excretion of sodium and chloride following the administration of sodium chloride is decreased as compared with the normal $(1-4)$. Similarly, the sweat concentration of sodium chloride has been shown to be lower than normal in cases of congestive heart failure (5). To explore the frequency of these disturbances of electrolyte excretion it seemed of interest to study the concentrations of electrolytes in the saliva of patients with congestive heart failure on a low-salt regimen and on a regular salt intake. Similar control studies were performed on non-cardiac subjects.

\section{EXPERIMENTAL}

Twenty-nine observations were made on 27 congestive heart failure patients receiving one gram of sodium chloride per day in their diet. There were 13 studies on 11 cardiac failure patients on a regular diet containing 10 grams of salt per day. Of these 11 cardiac patients on the regular diet four received supplemental sodium chloride (4 grams daily for periods up to 16 days).

Twelve control observations on ten non-cardiac subjects receiving the salt-poor regimen were obtained, while 16 non-cardiac subjects on the regular diet were studied.

\section{METHODS}

Saliva was collected in the morning from the fasting patient who chewed paraffin for 15 to 20 minutes, yielding about $30 \mathrm{cc}$. of saliva.

Whole, mixed saliva was analyzed. Sodium and potassium concentrations were obtained with an internal standard Perkin 52A flame photometer. Chloride concentrations were measured by the Van Slyke-Hiller iodometric method (6).

Standard methods of statistical analysis were employed (7).

\section{RESULTS}

Results are presented in Table I.

When data from studies on the low-salt regimen and on the regular diet are combined, it is seen that congestive heart failure is associated with

\footnotetext{
1 This work was done during the tenure of a Research Fellowship of the American Heart Association.

2 Resident in Medicine.
}

lowered sodium, lowered chloride, and higher potassium concentrations (mean concentrations) in saliva than is the case for the controls. There is no significant difference in electrolyte concentrations between congestive heart failure patients on a low-salt regimen and those on a regular diet. In contrast, non-cardiac, control subjects on a low salt regimen show a significantly lower average concentration of salivary sodium and chloride than those controls receiving a regular diet.

Thus, the salivas of subjects on salt-poor diets do not show significant difference in mean electrolyte concentrations between congestive heart failure patients and non-cardiac controls. On the other hand, studies of subjects on regular diets emphasize the lowered saliva sodium and chloride concentrations in congestive heart failure noted above in reporting the combined data.

In this study, no correlation was found between the electrolyte concentrations of saliva and blood.

\section{DISCUSSION}

The saliva concentrations of sodium, chloride and potassium in the controls on the regular diet agree well with those reported previously (8-10).

McCance (11) observed that salt deficiency (produced during a period of seven to ten days by restriction of dietary salt intake and sweating in a radiant-heat bath for two hours every day) in five normal subjects produced a consistent fall in the concentration of salivary sodium and rise in the concentration of potassium, while the changes in chloride concentration were inconsistent. In each of our seven control subjects who were changed directly from a normal diet to a salt-poor regimen, the sodium and chloride concentrations fell while that of the potassium rose.

Do the lower mean concentrations of sodium and chloride in saliva in chronic congestive heart failure represent an increased adrenal cortical activity, as has been postulated for sweat $(5,12)$ ? This might explain why increasing the daily salt 
TABLE I

The effect of congestive heart failure and diet on saliva electrolyte concentrations

\begin{tabular}{|c|c|c|c|c|c|c|c|c|c|c|c|}
\hline Patients & Diet & $\begin{array}{c}\text { Number } \\
\text { observations }\end{array}$ & \multicolumn{3}{|c|}{$\underset{\mathrm{mEq} / \mathrm{L}}{\mathrm{Na}}$} & \multicolumn{3}{|c|}{$\underset{\mathrm{mEq} / \mathrm{L}}{\mathrm{Cl}}$} & \multicolumn{3}{|c|}{$\underset{\mathrm{mEq} / \mathrm{L}}{\mathrm{K}}$} \\
\hline \multirow[t]{2}{*}{$\begin{array}{l}\text { Cong. ht. fail. (27) } \\
\text { Cong. ht. fail. (11) }\end{array}$} & $\begin{array}{l}\text { Salt-poor } \\
\text { Regular }\end{array}$ & $\begin{array}{l}29 \\
13\end{array}$ & $\begin{array}{c}\overline{\mathrm{x}} \\
18.6 \\
16.8\end{array}$ & $\begin{array}{l}S_{x} \\
9.3 \\
7.6\end{array}$ & $\begin{array}{l}S_{\bar{x}} \\
1.7 \\
2.1\end{array}$ & $\begin{array}{c}\bar{x} \\
22.1 \\
20.2\end{array}$ & $\begin{array}{l}S_{x} \\
8.7 \\
6.6\end{array}$ & $\begin{array}{l}S_{\bar{x}} \\
1.6 \\
1.8\end{array}$ & $\begin{array}{c}\bar{x} \\
25.0 \\
22.3\end{array}$ & $\begin{array}{l}S_{x} \\
4.7 \\
4.9\end{array}$ & $\begin{array}{l}S_{\bar{x}} \\
0.9 \\
1.4\end{array}$ \\
\hline & $\begin{array}{l}\mathrm{t} \\
\mathrm{p}\end{array}$ & & \multicolumn{3}{|c|}{$\begin{array}{l}0.64 \\
0.62\end{array}$} & \multicolumn{3}{|c|}{$\begin{array}{l}0.77 \\
0.55\end{array}$} & \multicolumn{3}{|c|}{$\begin{array}{l}1.65 \\
0.12\end{array}$} \\
\hline \multirow[t]{2}{*}{$\begin{array}{l}\text { Controls (10) } \\
\text { Controls (16) }\end{array}$} & $\begin{array}{l}\text { Salt-poor } \\
\text { Regular }\end{array}$ & $\begin{array}{l}12 \\
16\end{array}$ & $\begin{array}{l}17.6 \\
33.1\end{array}$ & $\begin{array}{l}10.2 \\
13.4\end{array}$ & $\begin{array}{l}3.0 \\
3.4\end{array}$ & $\begin{array}{l}21.6 \\
33.9\end{array}$ & $\begin{array}{r}6.3 \\
10.2\end{array}$ & $\begin{array}{l}1.8 \\
2.5\end{array}$ & $\begin{array}{l}22.0 \\
19.5\end{array}$ & $\begin{array}{l}5.8 \\
3.4\end{array}$ & $\begin{array}{l}1.7 \\
0.9\end{array}$ \\
\hline & $\begin{array}{l}\mathrm{t} \\
\mathrm{p}\end{array}$ & & \multicolumn{3}{|c|}{$\begin{array}{l}2.95 \\
0.006\end{array}$} & \multicolumn{3}{|c|}{$\begin{array}{l}3.91 \\
0.0005\end{array}$} & \multicolumn{3}{|c|}{$\begin{array}{l}1.33 \\
0.20\end{array}$} \\
\hline \multirow[t]{2}{*}{$\begin{array}{l}\text { Cong. ht. fail. (28) } \\
\text { Controls (19) }\end{array}$} & $\begin{array}{l}\text { Combined } \\
\text { Combined }\end{array}$ & $\begin{array}{l}42 \\
28\end{array}$ & $\begin{array}{l}18.0 \\
26.5\end{array}$ & $\begin{array}{r}8.7 \\
14.3\end{array}$ & $\begin{array}{l}1.4 \\
2.7\end{array}$ & $\begin{array}{l}21.5 \\
28.6\end{array}$ & $\begin{array}{r}8.7 \\
10.7\end{array}$ & $\begin{array}{l}1.2 \\
2.0\end{array}$ & $\begin{array}{l}24.2 \\
20.6\end{array}$ & $\begin{array}{l}4.9 \\
4.6\end{array}$ & $\begin{array}{l}0.8 \\
0.9\end{array}$ \\
\hline & $\begin{array}{l}\mathrm{t} \\
\mathrm{p}\end{array}$ & & \multicolumn{3}{|c|}{$\begin{array}{l}2.81 \\
0.006\end{array}$} & \multicolumn{3}{|c|}{$\begin{array}{l}3.02 \\
0.003\end{array}$} & \multicolumn{3}{|c|}{$\begin{array}{l}3.09 \\
0.003\end{array}$} \\
\hline
\end{tabular}

$\overline{\mathbf{x}}=$ mean.

$S_{\mathbf{x}}=$ Standard deviation.

$S_{\overline{\mathbf{x}}}=$ Standard error of the mean.

$t=\frac{\bar{d}}{S_{\bar{d}}^{-}}$, where $\bar{d}=$ difference between the means

$\left(S_{\bar{d}}\right)^{2}=\left(S_{1} \bar{x}\right)^{2}+\left(S_{2} \bar{x}\right)^{2}$.

$p=$ probability $\left\{\begin{array}{l}\text { if } p=1.0, \text { then the observed difference is entirely a chance occurrence. } \\ \text { if } p=0.0 \text {, then there is no element of chance. }\end{array}\right.$

intake at least tenfold in cardiac failure patients for periods up to 16 days did not affect the saliva electrolyte concentrations. Increased adrenal cortical activity might promote retention of sodium and chloride by the salivary glands just as it does by the kidneys and sweat glands, despite an increased intake of salt.

Desoxycorticosterone acetate $(10 \mathrm{mgm}$. in oil, daily for three days) was administered to three cardiac failure patients on a low-salt regimen without any effect upon saliva electrolyte concentrations. This, too, is to be expected if we postulate an already enhanced adrenal cortical activity in these patients.

To investigate this question of enhanced adrenal cortical activity affecting salivary electrolyte concentrations, studies are in progress on the administration of desoxycorticosterone acetate for longer periods to normal subjects on a regular diet, and on patients receiving cortisone and ACTH. The salivary electrolyte concentrations in disorders of the adrenal cortex such as Addison's disease and
Cushing's syndrome will be of interest in this connection.

Since mercurial diuretics increase the excretion of sodium and chloride in urine, their effect on saliva electrolyte concentrations was studied. In two cardiac failure patients mercurial diuresis was without effect on the saliva electrolytes, determined 24 hours after the intramuscular injection of the diuretic. However, the saliva electrolytes were determined after the peak of mercurial diuresis. This study will be repeated with saliva specimens collected at earlier intervals following the injection of the diuretic.

\section{CONCLUSIONS}

1. Congestive heart failure is associated with lowered sodium, lowered chloride, and higher potassium average concentrations in saliva.

2. Studies of subjects on regular diets emphasize the lowered saliva sodium and chloride concentrations in congestive heart failure, but tend to minimize the higher potassium concentrations. 
3. Salivas of subjects on salt-poor diets do not show significant difference in electrolyte concentrations between congestive heart failure subjects and controls.

4. There is no relationship between serum electrolyte concentrations and those of saliva.

\section{BIBLIOGRAPHY}

1. Proger, S., Ginsburg, E., and Magendantz, H., Effects of ingestion of excessive amounts of sodium chloride and water on patients with heart disease. Am. Heart. J., 1942, 23, 555.

2. Schroeder, H. A., Studies on congestive heart failure; importance of restriction of salt as compared to water. Am. Heart. J., 1941, 22, 141.

3. Futcher, P. H., and Schroeder, H. A., Studies on congestive heart failure; impaired renal excretion of sodium chloride. Am. J. M. Sc., 1942, 204, 52.

4. Schemm, F. R., High fluid intake in management of edema, especially cardiac edema; details and basis of régime. Ann. Int. Med., 1942, 17, 952.

5. Merrill, A. J., Mechanisms of salt and water retention in heart failure. Am. J. M., 1949, 6, 357.

6. Van Slyke, D. D., and Hiller, A., Application of
Sendroy's iodometric chloride titration to protein-containing fluids. J. Biol. Chem., 1947, 167, 107.

7. Mather, K., Statistical Analysis in Biology. Interscience Publishers, Inc., New York, 1947, 2nd edition.

8. Ferris, H. C., Smith, E. E., and Graves, E. V., Physiological and pathological variations in the composition of the human saliva. J. Am. Dent. A., 1923, 10, 19.

9. Clark, G. W., and Shell, J. S., Influence of diet upon inorganic constituents of human saliva. Dental Cosmos, 1927, 69, 500.

10. Brown, J. B., and Klotz, N. J., Studies on the chemistry of mixed human saliva. I. Attempts to correlate chemical composition of mixed human saliva with rate of secretion. J. Dent. Research, 1934, 14, 434. II. Sodium, potassium and calcium in salivas secreted at widely varying rates. $J$. Dent. Research, 1937, 16, 19.

11. McCance, R. A., The effect of salt deficiency in man on the volume of the extracellular fluids, and on the composition of sweat, saliva, gastric juice and cerebrospinal fluid. J. Physiol., 1938, 92, 208.

12. Conn, J. W., Electrolyte composition of sweat. Arch. Int. Med., 1949, 83, 416. 